\title{
Different Disciplines in the Field of Suicide Study
}

\author{
Shan Cao ${ }^{1}$, Da-Yong Lu ${ }^{2 *}$, Ting-Ren Lü ${ }^{2}$ and Nagendra Sastry Yarla ${ }^{3}$ \\ ${ }^{1}$ Department of Art \& Design, Kyoto University, Japan \\ ${ }^{2}$ Department of Art \& Design, Shanghai University, PR China \\ ${ }^{3}$ Department of Art \& Design, GITAM University, India
}

Submission: May 24, 2017; Published: June 13, 2017

*Corresponding author: Da-Yong Lu, Department of Art \& Design, Shanghai University, Shanghai PR China, Email: ludayong@shu.edu.cn

Abstract

Human suicide risks and mortality predictions and preventions may be transformed from symptom-based prediction systems into pathogenic profiling-supportive diagnostic systems. In addition, specific, highly active and low-toxicity drug may be developed from the wide-spectra parameters of objective clinical data (genomics/bioinformatics/morphology systems). To attain this goal, updating pathways tailored for suicide/mental illness therapeutic improvements may be noticed and established in this article.

Keywords: Human suicide; Human genome; Pathology; Neuropsychology; Mood disorder; Disease diagnostics; Neural pharmacology

\section{Introduction}

Human suicide is a long-noticed medical problem [1]. Currently, suicide prediction, prevention and therapeutics have a number of limitations [2]. To overcome these limitations, genetic/molecular pathogenesis studies are indispensable [38]. Genetic/molecular pathogenesis study is the priority [9]. In future, human suicide risks and mortality predictions and clinical diagnostics may be transformed from symptom-based score-index into pathogenic profiling supportive diagnostics. In addition, high specific, low-risk drug therapeutics might be established via parameters of genomics/bioinformatics/ morphology systems [10]. This summary offers possible routes for further scientific investigations.

\section{Present Overview}

a. In future, following scientific avenues are inevitable; including

b. Genetic, molecular and brain visualizing from pathologic/diagnostic study must be undergone. Without clarifying these patterns of pathogenic information, highly effective target drugs cannot be developed; finding these lines of genetic evidence is the top priority [3-8].

c. In-vitro genetic or molecular models available for basic neural researches and large-scale in-vivo pharmacological study must be established [7].

d. Seek medications from multidisciplinary; a relatively new medication idea might be suitable to solve the therapeutic deficiency from wide-range symptom-based diagnostics into pathogenic dysfunction evaluations by modern technology and finalizing comprehensive therapeutics [8-11].

e. Previous clinical applications for bipolar II disorder patients show some drug therapeutic beneficial outcomes, further scientific and medical work is needed [12-14].

\section{Roadmap for Translational Study}

Integration of suicide/mental illness conditions (DSM-V, suicidal ideation risks and self-injures)-disease progression (patients' depression)-score index into one system (pharmacogenetics) [3-7]. Support new generation of medical hypotheses and objective in clinical diagnostics [8]. Finding effective patents that help implementing drug treatment and risk/response evaluating and therapeutic prediction systems before suicide/mental illness medications [6]. Investigate neural genes, biological molecules and visual dysfunctions by new techniques such as opto-genetics, genetic engineering mice (GEM) and so on [7]. Systems biology, mathematics and computational network, models and systems may play magic role for in-depth understanding of intrinsic relationships between diagnosis and therapies [15,16]. Growing sample size of human genomes (larger individuals and populations) and relationship between different genetics/bioinformatics and visual data by different types of drugs and pathogenesis pathways are underway [1]. Interplay relationship between genetics, molecular, chemical, environmental factors and drug (such as antidepressant) efficacies and neural toxicities (suicide risks) must be established [17]. 
Genome-wide association study (GWAS) between depressed patients and normal persons, ethnic groups/races, family inheritable diseases, genders or ages of different pathogenic conditions will be rapidly undergone [3]. Undertaking high intelligent animal models, such as primates in pathogenesis and therapeutic studies [3- 6]. Genetic or genomic study of repeated DNA in human genomes and make new discoveries from wider human genome studies [7]. Perfect the joint-specialists participation therapeutics for suicide/mental illness study and clinical applications [11]. Budget control and cost-effective studies of all these scientific investigations, clinical utilities and therapeutic prediction and evaluations [10].

\section{Conclusion}

By these kinds of scientific and medical investigations, we can make a big difference in the near future. We hope new breakthroughs will be under way soon.

\section{References}

1. Lu DY, Wu HY, Cao S, Lu Y, Yarla NS, et al. (2017) Historical analysis of suicide/mental disorder and current diagnostics in clinics. In: DaYong Lu[Eds.], Suicide Risks and Treatments, New Ideas and Future Perspectives ( $1^{\text {st }}$ edn), Nova Science Publishers, New York, US, pp. 1-12.

2. Lu DY, Lu TR, Zhu PP, Yarla NS, Wu HY (2017) Current suicide predictions, preventions and treatments. In: Da-Yong Lu[Eds.], Suicide Risks and Treatments, New Ideas and Future Perspectives ( $3^{\text {rd }}$ edn), Nova Science Publishers, New York, US pp. 25-38.

3. Lu DY, Lu TR, Zhu PP, Che JY (2015) Genetics and bioinformatics study of antidepressant drugs, recent advancements and future trends. In: Bradly Weaver[Eds.], Suicide Ideation: Predictions, Prevalence and Prevention ( $3^{\text {rd }}$ edn), Nava Science Publishing, US, pp. 57-71.

4. Serafini G, Salano P, Amore M (2015) Suicide ideation: a comprehensive overview. In: Bradly Weaver (Eds.), Suicide ideation: Predictions, Prevalence and Prevention ( $1^{\text {st }}$ edn), Nava Science Publishing, US, pp. $1-42$.

5. Read J, Runciman O, Dillon J (2016) In search of an evidence-based role for psychiatry. FSOA, 2(2): FSOA-2016-0011
6. Lu DY, Lu TR, Che JY, Zhu PP (2014) Genetics and bioinformatics studies of antidepressant drug therapeutic efficacies and toxicities, a current overview. Recent Pat CNS Drug Discov 9(3): 193-199.

7. Lu DY, Lu TR, Zhu PP (2013) Pharmacogenetics in neural toxicities of drugs. Pharmacogenomics 14(10): 1129-1131

8. Lu DY, Zhu PP, Wu HY, Lu Y, Che JY (2017) New modes of suicide/ mental disorder diagnostics and therapeutics. In: Da-Yong Lu (Eds.), Suicide Risks and Treatments, New Ideas and Future Perspectives (5 edn), Nova Science Publishers, New York, US pp. 51-62.

9. Lu DY, Che JY, Cao S, Chen Y, Wu HY (2017) Suicide risks and pathogenesis studies. In: Da-Yong Lu (Eds.), Suicide Risks and Treatments, New Ideas and Future Perspectives ( $4^{\text {th }}$ edn), Nova Science Publishers, New York, US, pp. 39-50.

10. Lu DY (2017) Suicide Risks and Treatments, New Ideas and Future Perspectives. In: Da-Yong Lu (Eds.), Nova Science Publishers, New York, US.

11. Lu DY, Zhu PP, Lu TR, Che JY (2017) The suicidal risks and treatments, seek medications from multi-disciplinary. Cent Nerv Syst Agents Med Chem 16(3): 231-239.

12. McAllister-Williams R, Ferrier IN (2009) Pharmacological management of unipolar affective disorder. Psychiatry 8(4): 113-119.

13. McAllister-Williams R, Ferrier IN (2009) Pharmacological management of bipolar affective disorder. Psychiatry 8(6): 120-124.

14. Lu DY, Lu TR, Ding J, Wu HY, Yarla, et al. (2017) Therapeutic drug developments and clinical utilities. In: Da-Yong Lu [Eds.], Suicide Risks and Treatments, New Ideas and Future Perspectives ( $6^{\text {th }}$ edn), Nova Science Publishers, New York, US, pp. 63-72.

15. Lu DY, Lu TR (2015) Mathematics or physics-majored students on the biomedical fields, insiders or outsiders? Metabolomics 5(4): e142.

16. Lu DY, Wu HY, Lu TR, Che JY, Lu Y (2016) Updating biomedical studies by recruiting more mathematics or physics-majored talents. Metabolomics 6(2): e148.

17. Lu DY, Lu TR, Zhu PP, Cao S (2017) Different ranges of outside factors upon human suicidal rates and mortalities. In: Da-Yong Lu (Eds.), Suicide Risks and Treatments, New Ideas and Future Perspectives ( $2^{\text {nd }}$ edn), Nova Science Publishers, New York, US, pp. 13-24.

\section{Your next submission with Juniper Publishers will reach you the below assets}

- Quality Editorial service

- Swift Peer Review

- Reprints availability

- E-prints Service

- Manuscript Podcast for convenient understanding

- Global attainment for your research

- Manuscript accessibility in different formats ( Pdf, E-pub, Full Text, Audio)

- Unceasing customer service

Track the below URL for one-step submission https://juniperpublishers.com/online-submission.php 